\title{
Influence of palaeoenvironmental factors on the encystment of Cretaceous dinoflagellate cysts (Ceratiaceae): a study from Godavari Graben, Southern India
}

Edwige Masure, Neerja Jha, Sarah Gonçalves Duarte, Neha Aggarwal, Mitsuru Arai \& Harinam Joshi

To cite this article: Edwige Masure, Neerja Jha, Sarah Gonçalves Duarte, Neha Aggarwal, Mitsuru Arai \& Harinam Joshi (2017) Influence of palaeoenvironmental factors on the encystment of Cretaceous dinoflagellate cysts (Ceratiaceae): a study from Godavari Graben, Southern India, Palynology, 41:4, 472-483, DOI: 10.1080/01916122.2016.1262922

To link to this article: https://doi.org/10.1080/01916122.2016.1262922

View supplementary material ¿

Accepted author version posted online: 29

Nov 2016.

Published online: 10 Apr 2017.

Submit your article to this journal $\widetilde{T}$

山ll Article views: 156

View Crossmark data ¿

Citing articles: 1 View citing articles $\sqsubset$ 


\title{
Influence of palaeoenvironmental factors on the encystment of Cretaceous dinoflagellate cysts (Ceratiaceae): a study from Godavari Graben, Southern India
}

\author{
Edwige Masure ${ }^{a}$, Neerja Jha ${ }^{b}$, Sarah Gonçalves Duarte ${ }^{c}$, Neha Aggarwal $^{b}$, Mitsuru Arai $^{d}$ and Harinam Joshi ${ }^{\mathrm{b}}$ \\ ${ }^{a}$ Centre de Recherche sur la Paléobiodiversité et les Paléoenvironnements, CR2P, UMR 7207, MNHN, UPMC, CNRS, Université Pierre et Marie Curie, \\ 4 place Jussieu, 75005 Paris, France; ${ }^{b}$ Birbal Sahni Institute of Palaeosciences, 53 University Road, Lucknow, India; ' UFRJ, 274 Av. Athos da Silveira \\ Ramos, Maths and Natural Science Center, Department of Geology, University City, Rio de Janeiro, Ilha do Fundão, 21949-916, Brazil; 'UNESP (São \\ Paulo State University), IGCE/UNESPetro. 13501-070 Rio Claro-SP, Brazil
}

\begin{abstract}
Muderongia staurota forms with long appendages at the distal end of the apical, lateral and antapical horns have been recovered from the Lower Cretaceous Gangapur Formation of Upper Gondwana sequence from the Chintalapudi Sub-Basin (India). The number of distal appendages reflects the number of plates forming the horns. We include these forms in the new species Muderongia gangapurensis sp. nov. The dinoflagellate cysts recovered suggest a late Berriasian to Valanginian for the lower part and a Hauterivian/Barremian age for the upper part of the studied interval of MJR-11 borehole. Unusual Muderongia and Odontochitina cysts bearing similar long appendages have only occasionally been described or illustrated in the literature from sediments rich in continental organic matter. We suggest that Cretaceous Ceratiaceae bearing such appendages are cysts of thecae that encysted in particular environments, where light, salinity, temperature and chemistry of water masses might have been key to their development. Our conclusion is supported by the high morphological variability of horns in modern Ceratiaceae, which reflects environmental factors. We discuss the plasticity of horns in the fossil record and note that such plasticity is recurring in Ceratiaceae, at least in the Early Cretaceous (145 Ma).
\end{abstract}

\section{KEYWORDS}

Dinoflagellate cysts; Ceratiaceae; Muderongia; India; Cretaceous

\section{Introduction}

The Ceratiaceae encompass a group of extant dinoflagellates having three or more prominent horns and inhabiting both freshwater and marine environments, as well as marine representatives from the latest Jurassic to the latest Cretaceous. Living and fossil Ceratiaceae are the only Gonyaulacales family to develop lateral horns. Although occurring worldwide, extant Ceratiaceae are most common in temperate areas. They are harmless, non-toxic organisms, but can produce red tides, if conditions allow for excessive blooming, causing a strain on the ecosystem (eutrophication). Ceratium tetraceros Schrank 1793 is the type species of the genus Ceratium described by Cleve (1900). Ceratium hirundinella is a taxonomic junior synonym of C. tetraceros (Müller 1786). Based on the shape of the cell body and the horns, Vanhöffen (1896) proposed to include some species of Ceratium in three new genera: Amphiceratium, Biceratium or Proceratium. However, Kofoid (1907) retained all the species in Ceratium, since the four genera have the same tabulation. Subsequent authors treated Vanhöffen's genera as subgenera (Gran 1902; Ostenfeld 1903; Paulsen 1908; Sournia 1967). Wall \& Evitt (1975) proposed the following tabulation: 4', 0a, 6", 5-6c, $6 " ', 1 p, 1$ '"', plus two or more sulcal platelets, suggesting a gonyaulacoid affinity. According to these authors, the right lateral horn, the larger, is formed by postcingular plates 4 "' dorsally and $5^{\prime \prime \prime}$ ventrally. The left lateral accessory horn is formed by postcingular plates $1^{\prime \prime \prime}$ ventrally and $2^{\prime \prime \prime}$ dorsally. Wall \&
Evitt's (1975) interpretation - i.e Ceratium with one antapical $\left(1^{\prime \prime \prime \prime)}\right.$ and one posterior intercalary plate (1p) instead of two antapical plates (1'"', 2"'") - was not accepted by some further authors (Sournia 1986; Balech 1988; Steidinger \& Tangen 1997; Temponeras et al. 2000).

Based on small subunit ribosomal RNA genes (SSU rDNA) and the number of cingular plates, Gómez et al. (2010) proposed a new genus name, Neoceratium, for all marine species currently assigned to Ceratium and designated Neoceratium furca as the type species. The freshwater species, including Ceratium hirundinella (taxonomic junior synonym of the type species), form a subclade distinct from the marine cluster. Freshwater Ceratium species possess six cingular plates, while marine Neoceratium species possess five; according to Gómez et al. (2010), the number of cingular plates is the most robust morphological character for separating the two genera. Previously, Sournia (1984) had suggested that the marine species of Ceratium could be included in a new genus. The genus Neoceratium is a potential indicator of ocean warming (Tunin-Ley \& Lemée 2013).

For many years, resting cysts of Ceratium were known only in freshwater species (Entz 1925; Wall \& Evitt 1975; Sournia 1986). However, Gómez et al. (2010) observed resting cysts of the marine species Neoceratium furca and Neoceratium candelabrum (fig. 6 in Gómez et al. 2010) in some samples. Thus, species of freshwater Ceratium and marine Neoceratium can develop cellulosic resting cysts. Wall \& Evitt $(1975$, p. 25$)$ noted

CONTACT Edwige Masure edwige.masure@upmc.fr

(4) Supplemental data for this article can be accessed at $\mathrm{https} / /$ doi.org/10.1080/01916122.2016.1262922.

(c) 2017 AASP - The Palynological Society 
that freshwater Ceratium cysts would not be preserved below a depth of 1 or $2 \mathrm{~cm}$ in lake and also presumably marine, sediments. Such cysts could have evolved in latest Cretaceous marine ceratiaceans, thus explaining why ceratiacean cysts have not been recovered from Cenozoic sediments.

Evitt (1985, p. 210-212) included fossil ceratiacean cysts (GcCysts) in his gonyaulacoid configuration. The Gc-Cysts are distinguished by having mainly three or four horns: one apical and two or three hypocystal horns, one from the $1 \mathrm{p} / 1^{\prime \prime \prime}$ suture and the other from the sutures of the left and right sides between the two postcingulars $1^{\prime \prime \prime}$ and $2^{\prime \prime \prime}$ and 4 "' and 5"', just like the antapical and lateral horns of Ceratium. On the ventral surface in Gc-Cysts, there are two precingular plates on the right and one plate on the left of the sulcal notch. The tabulation of Cretaceous ceratioids has been described from Muderongia sp. cf. $M$. mowhaei cysts (Wall \& Evitt 1975), Endoceratium dettmannae, Muderongia sp., Pseudoceratium sp. (Harding \& Hughes 1990) and Odontochitina tabulata (El-Mehdawi 1998). In Muderongia, lateral horns have a broad-based proximal part in line with the cingulum, with or without a thin distal part extending in the posterior direction. Plates involved in formation of the proximal part of the left lateral horn are the precingulars 1" and 2", one or two cingular(s) and the postcingulars 1"' and 2"'. The proximal part of the right lateral horn incorporates the precingulars 4 " and 5", one or two cingular(s) and the postcingulars 4"' and 5 "' plates. Postcingular plates 1 "'-2"' and 4 "'-5"' form the distal parts of the left and right lateral horns.
The Gc-Cysts include six genera: Endoceratium, Muderongia, Odontochitina, Phoberocysta, Pseudoceratium and Xenascus. Pseudoceratium is acavate, whereas the other genera are cavate with a subspherical central body (Evitt 1985). Bint (1986) noted that the tabulation of ceratioid cysts is characterized by having planate 1" and camerate 2" anteriorly, whereas gonyaulacoid cysts have camerate 1" and planate 2" anteriorly. Bint (1986) accepted Evitt's list in the Ceratiaceae and included four other genera; these were: ?Australisphaera, Balmula, Nyktericysta and Vesperopsis. In these four genera the endophragm and periphragm are adpressed and a subspherical central body is absent. Fensome et al. (1993) placed the family Ceratiaceae in the Gonyaulacales and added to Bint's list by also including Ceratium, Aptea and Odontochitinopsis. A central body is absent in Aptea but present in Odontochitinopsis. Mao Shaozhi et al. (1999) described the genus Quantouendinium and demonstrated its ceratioid-style tabulation. Quantouendinium and Nyktericysta are two-layered cysts without a subspherical central body. The endophragm is closely adpressed to the periphragm; the endophragm extends into the horns but not the tips of the horns in Nyktericysta or the tip of the apical horn in Quantouendinium.

The periphragm and autophragm of species of these 13 genera bear different ornamentation that can be processes, perforations or appendages. In this paper we describe a new species close to Muderongia staurota, Muderongia gangapurensis sp. nov., which is characterized by having filamentous appendages at the distal end of the horns. Our observations allow us to

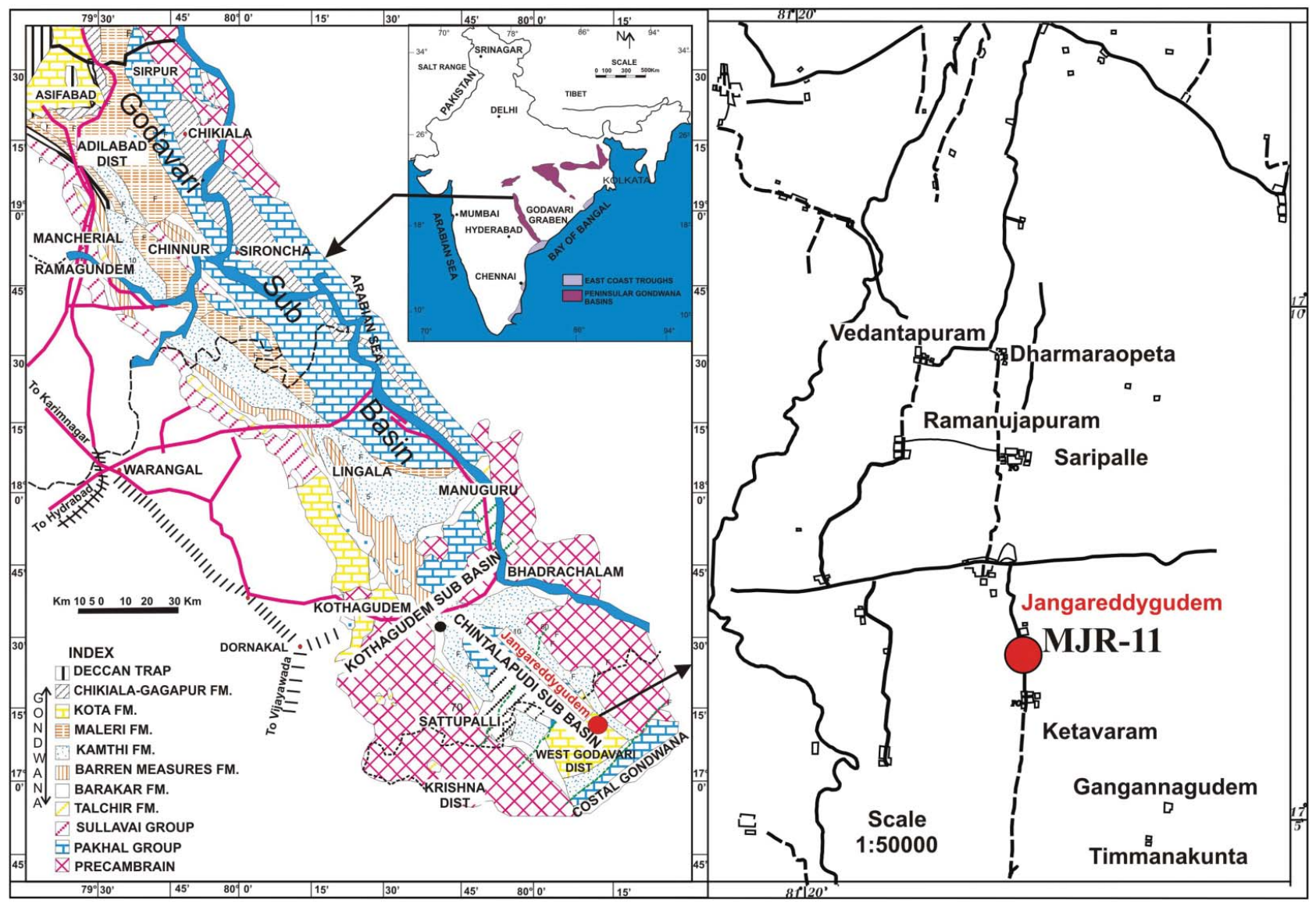

Figure 1. Map of Chintalapudi Sub-Basin, Godavari Graben, Andhra Pradesh, South India, with location of MJR-11 borehole. 
discuss the morphological variability of horns in fossil and living Ceratiaceae, and their relationship to environmental factors.

\section{Material and method}

The samples for our study were collected from the Jangareddygudem area of the Chintalapudi Sub-Basin, Godavari Graben, Andhra Pradesh, South India (Figure 1). All the sediments come from the MJR-11 borehole drilled by Mineral Exploration Corporation Limited, in the Gangapur Formation of the Upper Gondwana Group (Lakshminarayana \& Murti 1990). The objectives of the study were to use palynomorphs to correlate and date the sediments, in order to have a better understanding of the stratigraphy of the sub-basin. About 100 samples of different lithology were collected from the MJR-11 borehole; only marine assemblages with dinoflagellate cysts associated with miospores and dispersed organic matter are herein studied, between $126.20 \mathrm{~m}$ and $36.50 \mathrm{~m}$. Those samples between $49.50 \mathrm{~m}$ and $36.50 \mathrm{~m}$ yield Muderongia gangapurensis sp. nov. Based on megafloral assemblages, the age is Late Jurassic to Early Cretaceous for the Upper Gondwana Group (Bose et al. 1982; Sukh-Dev \& Rajanikanth 1988) and Early Cretaceous for the Gangapur Formation (Vijaya 1999). Recently, Jha Prakash \& Joshi (2016) reported megafossil impressions in the studied MJR-11 borehole in much deeper sediments (293.60-398 m depth) indicating Jurassic-Cretaceous age. A rich, well- preserved palynoassemblage has been recorded in these megafossil-bearing beds, but without any marine influence.

For recovery of palynomorphs, the samples were processed using standard maceration techniques (Bharadwaj \& Saluja 1964), specifically concentrated acids and alkali. About $15-25 \mathrm{~g}$ of sample crushed to about 2-3-mm size was first treated with hydrofluoric acid $(40 \%)$ to remove silicates, followed by treatment with nitric acid (63\%) to oxidize the humic matter and lastly by $10 \%$ potassium hydroxide to clear the palynomorphs. The residues were sieved through a $400 \mu \mathrm{m}$ mesh size screen. Thorough washing with distilled water was undertaken after each treatment. Residues were mounted using polyvinyl chloride (PVC) and Canada balsam. The morphological studies were carried out using an Olympus BX61microscope, and photography was done with a DP25 camera. All the slides are housed in Birbal Sahni Institute of Palaeosciences Museum (BSIP).

\section{Results}

\subsection{Biostratigraphy}

The biostratigraphy is herein based on dinoflagellate cysts (Figure 2). The level $126.20 \mathrm{~m}$ contains Cassiculosphaeridia magna (Plate 1, figure 2), Gagiella mutabilis sensu K-A, J 1992 (Plate 1, figure 5), Sentusidinium sp. 1 (Plate 1, figures 3-4), and acritarchs (Plate 1, figure 1). Khowaja-Ateequzzaman \& Jain (1992, pl. 3, figs 2-3,12-13) recorded Gagiella mutabilis in the upper Berriasian

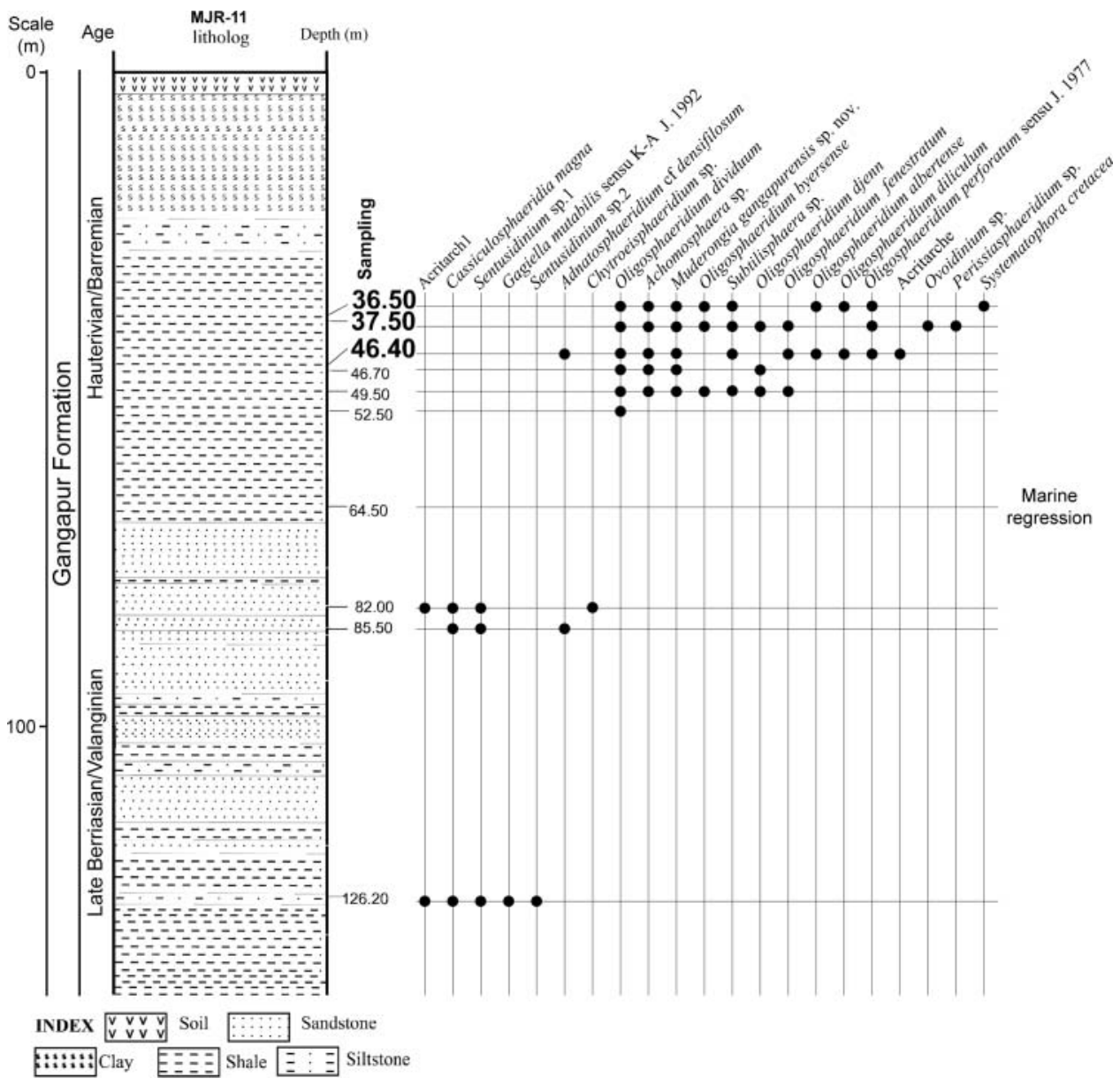

Figure 2. Distribution of dinoflagellate cysts from the MJR-11 borehole with lithological column. 

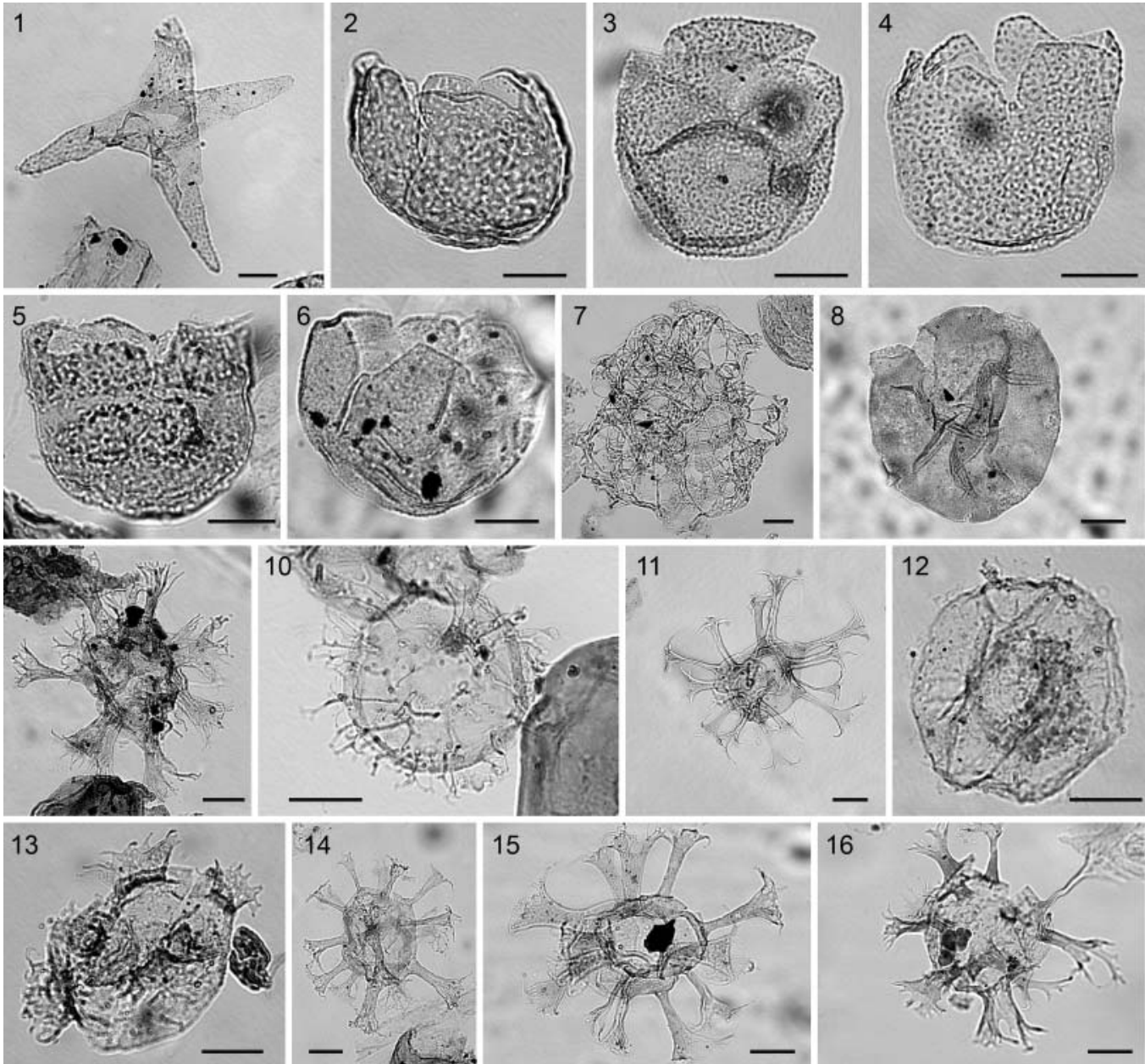

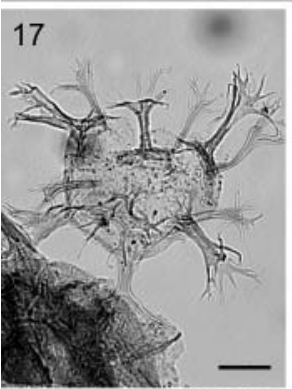

18
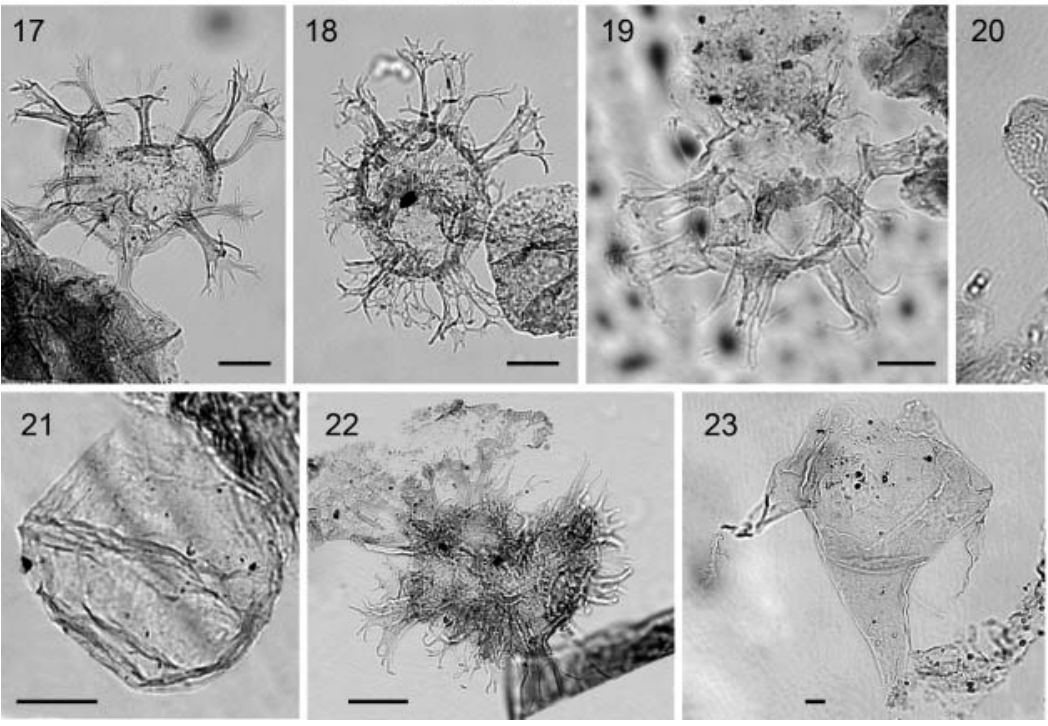

24

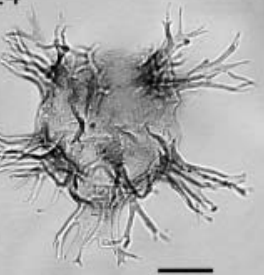

Plate 1. Dinoflagellate cysts from the MJR-11 borehole between 126.20 and 36.50 m, Gangapur Formation of the Chintalapudi Sub-Basin, Andhra Pradesh, India; co-ordinates: Graticule England Finder (GEF). Scale bars $=20 \mu \mathrm{m}$.

1: Acritarch, quadrishape form with long horns, thin and smooth to granular autophragm, granules well developed at the distal end of horns, MJR-11 $126.20 \mathrm{~m}$, BSIP Museum slide no. 16108 GEF: V53-1. 2: Cassiculosphaeridia magna, autophragm thick ornamented by a low coarse irregular reticulum; borehole MJR-11 85.50 m, BSIP Museum slide no. 15346 GEF: Y41. 3: Sentusidinium sp. 1, MJR-11 126.20 m, BSIP Museum slide no. 15456 GEF: N49-1. 4: Sentusidinium sp. 1, MJR-11 85.50 m, BSIP Museum slide no. 15346 GEF: Y38. 5: Gagiella mutabilis sensu Khowaja-Ateequzzaman \& Jain 1992, cyst without ornamentation on the cingulum and along pandasutural bands (Evitt 1985, p. 71) living theca: zones of incremental plate growth intercalated along thecal sutures cyst: they are clearly represented in some fossils by what have been called pandasutural bands or pandasutures (Evitt 1985, p. 71) MJR-11 126.20 m, BSIP Museum slide no. 15456 GEF: 051-2. 6: Sentusidinium sp. 2, MJR-11 126.20 m, BSIP Museum slide no. 15456 GEF: T52. 7: Adnatosphaeridium cf densifilosum, MJR-11 85.50 m, BSIP Museum slide no. 15346, GEF: Y37. 8: Chytroeisphaeridium sp., MJR-11 82 m, BSIP Museum slide no. 16106 GEF: M66-1/3. 9: Oligosphaeridium dividuum, MJR-11 52.50 m, BSIP Museum slide no. 16105 GEF: X35. 10: Achomosphaera sp., MJR-11 36.50 m, BSIP Museum slide no. 15621 GEF: H57-3. 11: Oligosphaeridium byersense, MJR-11 36.50 m, BSIP Museum slide no. 15625 GEF: H39. 12: Subtilisphaera sp., MJR-11 49.50 m, BSIP Museum slide no. 16104 GEF: W46-3. 13: Oligosphaeridium djenn, MJR-11 49.50 m, BSIP Museum slide no. 16104 GEF: X46-1. 14. Oligosphaeridium fenestratum, MJR-11 37.50 m, BSIP Museum slide no. 15626 GEF: U52. 15: Oligosphaeridium albertense, MJR-11 37.50 m, BSIP Museum slide no. 15626 GEF: H81-2. 16: Oligosphaeridium diliculum, MJR-11 36.50 m, BSIP Museum slide no. 15625 GEF: T53-4. 17: Oligosphaeridium dividuum, MJR-11 37.50 m, BSIP Museum slide no. 16109 GEF: Q65. 18: Perisseiasphaeridium sp., MJR-11 37.50 m, BSIP Museum slide no. 15626 GEF: O65-2. 19: Oligosphaeridium perforatum sensu Jain 1977, MJR-11 37.50 m, BSIP Museum slide no. 15627 GEF: Q63-1. 20: Acritarch, MJR-11 46.40 m, BSIP Museum slide no. 15628 GEF: R51-2. Note the absence of central body for attribution to freshwater Tetraguladinium conspicuum and the absence of tabulation for the genus Horologinella. $21:$ Ovoidinium sp., MJR-11 37.50 m, BSIP Museum slide no. 15627 GEF: V54. 22: Systematophora cretacea, note the cingular septa MJR-11 36.50 m, BSIP Museum slide no. 15624 GEF: O62. 23: Muderongia gangapurensis sp. nov., MJR-11 36.50 m, BSIP Museum slide no. 15623 GEF: T49-4. 24: Oligosphaeridium cf. dividuum, MJR-11 36.50 m, BSIP Museum slide no. 16111 GEF: T60-2. 
and Valanginian (Table 2, no. 40) rocks of Palar Basin, southern India, and noted its restricted stratigraphical distribution. Gagiella mutabilis has not been observed in younger sediments of the MJR-11 borehole. Adnatosphaeridium cf. densifilosum (Plate 1, figure 7) is present at level $85.50 \mathrm{~m}$, with Cassiculosphaeridia and Sentusidinium. Samples from $52.50 \mathrm{~m}$ recorded the first presence of Oligosphaeridium species with O. dividuum (52.50-36.50 m). Oligosphaeridium dividuum (Plate 1, figure 9) has been recorded from the Valanginian to Barremian offshore West Africa (Williams 1978). Oligosphaeridium byersense (Plate 1, figure 11) and O. djenn (Plate 1, figure 13) are present at level $49.50 \mathrm{~m}$, associated with Muderongia gangapurensis sp. nov. (Plate 1, figure 23). Oligosphaeridium byersense and $O$. djenn have been recorded in the Valanginian of Antarctica (Duane 1997) and in the Barremian offshore Morocco (Below 1982), respectively. Muderongia staurota has not been observed; all specimens have appendices located at the distal part of horns. In the Southern Hemisphere, Muderongia staurota occurs in upper Neocomian to Aptian rocks of Australia (Morgan 1980). The stratigraphic range of Muderongia staurota in India is known from the Hauterivian to Aptian (Garg et al. 1987, table 4; Khowaja-Ateequzzaman \& Jain 1992). Helby et al. (1987) did not record Muderongia staurota from the Muderongia testudinaria Interval Zone (middle Hauterivian), the $M$. australis Oppel Zone (Late Hauterivian to Barremian) or the Muderongia Super Zone (Early Valanginian to Early Albian). In the Northern Hemisphere, Muderongia staurota has a stratigraphic range of Late Hauterivian to middle Aptian (northwest Europe, Costa \& Davey 1992). We note the absence of Odontochitina operculata (Aptian, Southern Hemisphere) (Helby et al. 1987).

The studied interval of 126.20 to $36.50 \mathrm{~m}$ of the MJR-11 borehole is Early Cretaceous in age; the lower part from 126.20 to $82 \mathrm{~m}$ may be late Berriasian/Nalanginian, and an Hauterivian/Barremian age is suggested for the upper part, from 52.50 to $36.50 \mathrm{~m}$.

\subsection{Palynofacies}

Marine and continental ratios change along the studied section of the MJR-11 borehole (Figure 3). At a level of $126.20 \mathrm{~m}$, dinoflagellate cysts represent less than $10 \%$. In contrast, at levels of $85.5 \mathrm{~m}$ and $82 \mathrm{~m}$, the marine ratio reaches $50 \%$ and $60 \%$, respectively. The marine ratio falls in level $64.50 \mathrm{~m}(0 \%)$, then increases in $52.50 \mathrm{~m} \mathrm{(30 \% )}$ and $49.5 \mathrm{~m} \mathrm{(20 \% ),} \mathrm{up} \mathrm{to} 63 \%$ in level

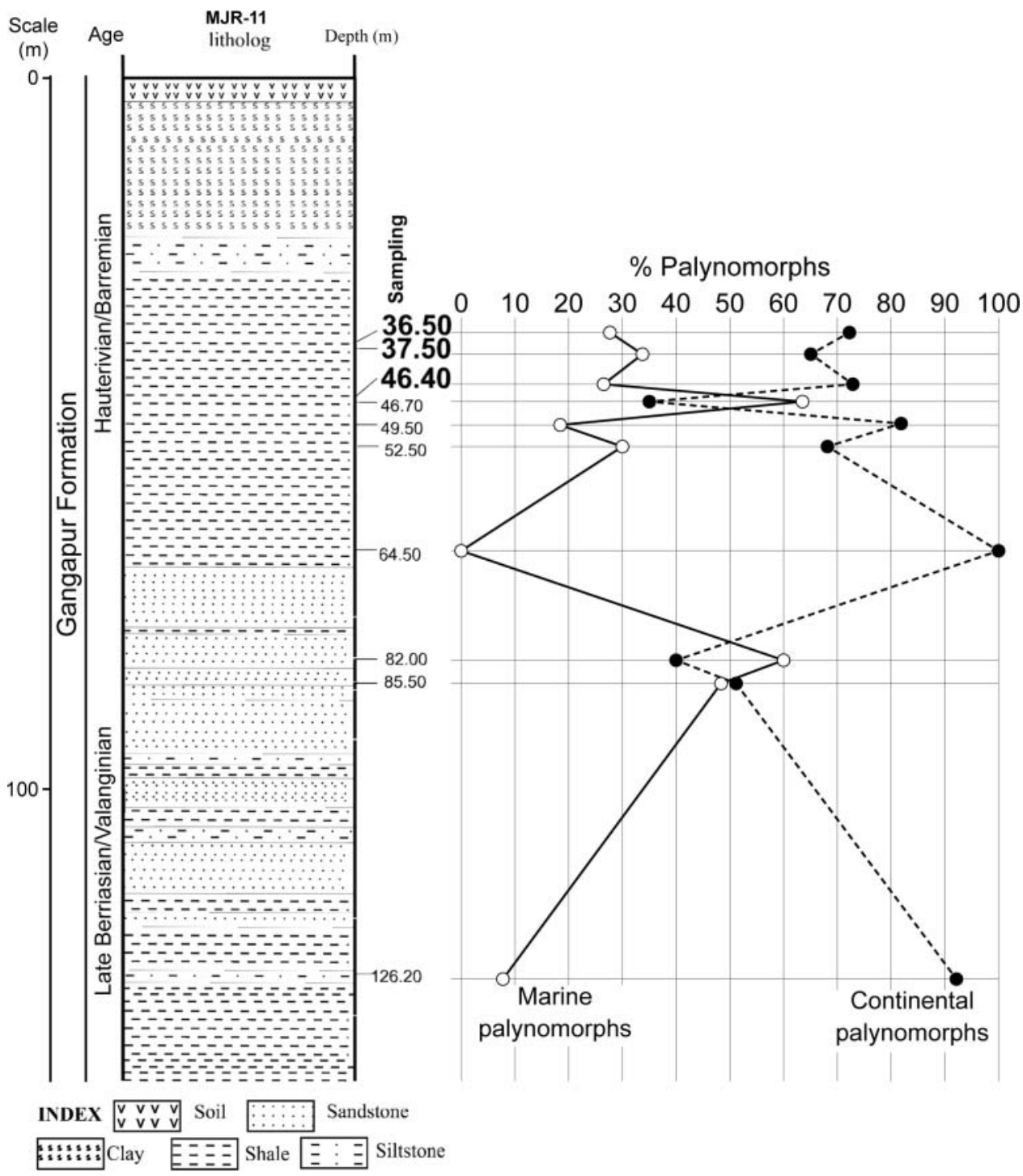

Figure 3. Marine and continental palynomorph ratios from the MJR-11 borehole. 

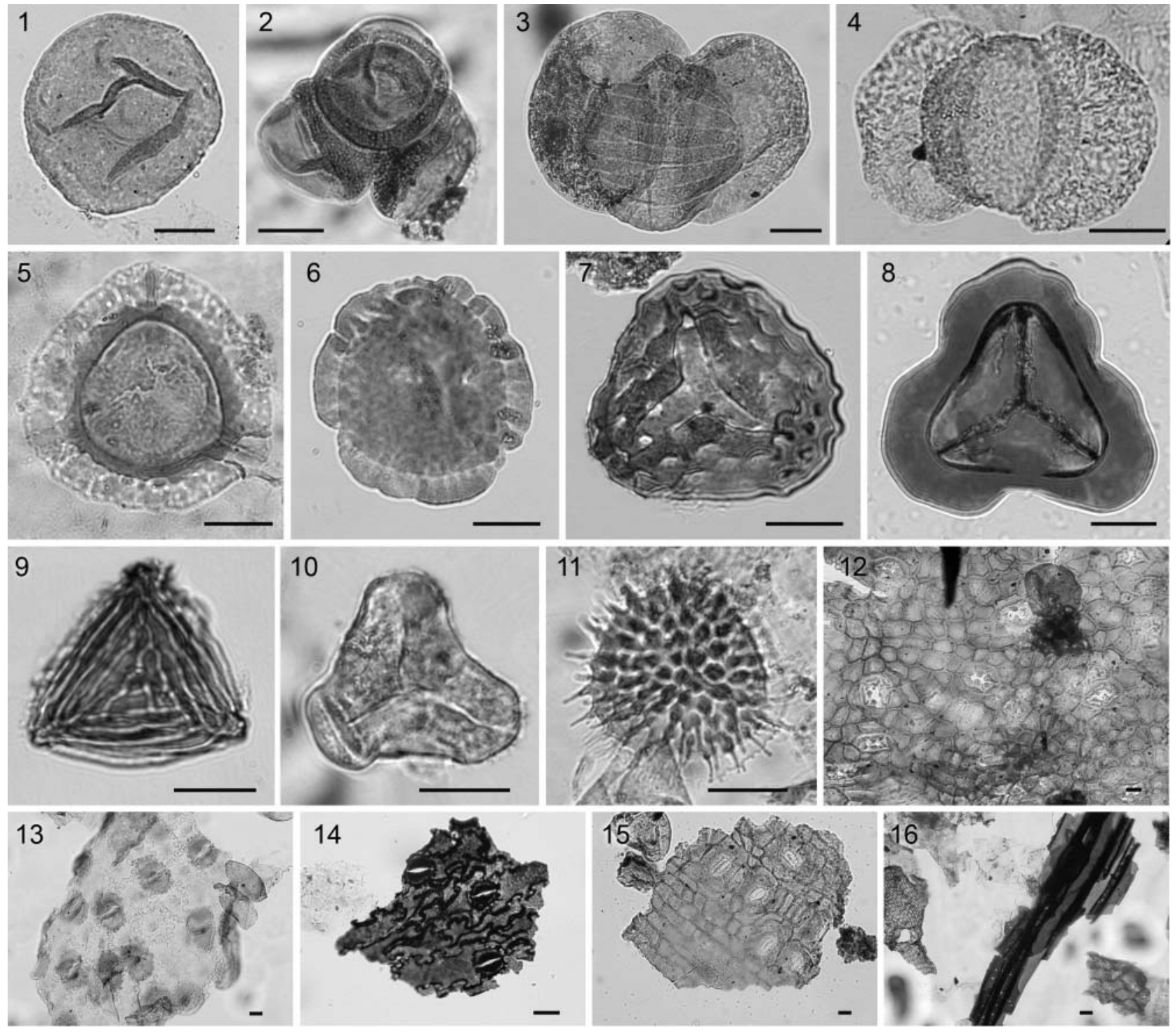

Plate 2. Continental palynomorphs from the Gangapur Formation of the Chintalapudi Sub-Basin, Andhra Pradesh, India; co-ordinates: Graticule England Finder (GEF). Scale bars $=20 \mu \mathrm{m}$.

1: Araucariacites australis, MJR-11 49.50 m, BSIP Museum slide no. 16112 GEF: U54-1. 2: Classopollis classoides tetrad, MJR-11 37.50 m, BSIP Museum slide no. 16110 GEF: T37-3. 3: Striatopodocarpites sp., MJR-11 126.20 m, BSIP Museum slide no. 16108 GEF: W41-1. 4: Podocarpidites sp., MJR-11 37.50 m, BSIP Museum slide no. 16108 GEF: K51. 5: Aequitriradites sp., MJR-11 37.50 m, BSIP Museum slide no. 15625 GEF: V40-1. 6: Callialasporites trilobatus, MJR-11 46.40 m, BSIP Museum slide no. 15628 GEF: W31-4. 7: Klukisporites scaberis MJR-11 37.50 m, BSIP Museum slide no. 16110 GEF: O64-3. 8: Murospora florida, MJR-11 37.50 m, BSIP Museum slide no. 16110 GEF: M48-3. 9: Plicatella sp., MJR-11 49.50 m, BSIP Museum slide no. 16112 GEF: H58-3. 10: Cyathidites sp., MJR-11 46.40 m, BSIP Museum slide no. 15260 GEF:E41-3. 11: Ceratosporites equalis, BSIP Museum slide no, 15260 GEF:049-3. 12: Cuticle, MJR-11 64.50 m, BSIP Museum slide no. 15260 GEF: X65-2. 13: Cuticle, MJR-11 36.50 m, BSIP Museum slide no. 15625 GEF: J41-2. 14: Cuticle, MJR-11 36.50 m, BSIP Museum slide no. 15625 GEF: P50-1. 15: Cuticle, MJR-11 49.50 mm, BSIP Museum slide no. 16112 GEF: P43-2. 16: Wood piece, MJR-11 36.50 m, BSIP Museum slide no. 15625 GEF: K35.

$46.70 \mathrm{~m}$. In upper levels $(46.40-36.50 \mathrm{~m})$ the marine parts stay around $30 \%$. The diversity of dinoflagellate assemblages is poor in levels 126.20 to $82 \mathrm{~m}$; they are dominated by species of Sentusidinium, Cassiculosphaeridia and Gagiella mutabilis sensu K-A J. 1992. After the non-marine interval $(64.50 \mathrm{~m})$, dinoflagellate cyst assemblages change and are dominated by Oligosphaeridium species from 52.50 to $36.50 \mathrm{~m}$. The diversity of dinoflagellate cysts progresses in levels of 46.50 and $36.50 \mathrm{~m}$, where the marine ratios are low (30\%). The two assemblages are related by sediments; sandstone and siltstone of the lower part yield Sentusidinium, Cassiculosphaeridia and Gagiella mutabilis sensu K-A J. 1992, while the shales of the upper part yield Oligosphaeridium species and Muderongia gangapurensis sp. nov.

Throughout the studied interval of the borehole MJR-11, the slides contain numerous organic particles such as cuticles with stomats well preserved (Plate 2, figures 12-15), tiny pieces of wood (Plate 2, figure 16), spores (Plate 2, figures 5-11), Araucariacites (Plate 2, figure 1), Classopollis (Plate 2, figure 2) and bisaccate pollen grains (Plate 2, figures 3-4). The abundance of continental particles suggests that the marine site of the borehole was under a fluvio-deltaic environment during the Early Cretaceous, and it recorded a marine regression. According to seasonal inputs of fluvial material, the salinity, temperature and chemistry of water masses of the delta environment presumably varied.

\section{Discussion}

In the systematics of living thecae or Cretaceous cysts, the horns of Ceratiaceae have been a major morphological characteristic used to separate taxa. The living marine theca species 
have hypocystal horns orientated in an anterior or posterior directions. But all marine fossil Ceratiaceae have hypocystal horns orientated in the posterior direction, as does the living freshwater Ceratium, and lack hypocystal horns orientated in the anterior direction, like those of some modern marine Neoceratium.

\subsection{Morphological variability of horns in living ceratiacean thecae and cysts}

The high morphological variability of horns of extant thecae that is triggered by environmental factors is well known. Marine Ceratiaceae show a considerable variation in horn size and shape resulting from seasonality (Dowidar 1972). Regeneration of horns has been noted (Kofoid 1908, 1909; Nielsen 1956; Wall \& Evitt 1975; Taylor 1987), and forms with horn appendages of different length (as fingers) or without such structures are well known (Balech 1988). The distinct morphotypes, sometimes spatially and temporally separated, and sometimes co-occurring, have been suggested to represent the existence of a species complex or forms with thermal preferences (Sournia 1967). Neoceratium ranipes thecae display remarkable appendages at the distal end of lateral and antapical horns (Cleve 1900). Neoceratium ranipes has three to seven finger-like appendages, which can vary considerably in length (buds to long appendages). Pizay et al. (2009) demonstrated for the first time that a single individual of Neoceratium ranipes is devoid of fingers in the night but develops them during the day. This is because the Neoceratium ranipes theca sacrifices swimming ability for increased photosynthetic capability during the hours of daylight. The species shows a circadian rhythm with highly diurnal polymorphism by growing finger-like appendages. The plasticity of the theca demonstrates its capacity to adjust to changing environmental conditions.

Entz (1925) noted that the size of cysts of freshwater Ceratium varies less than that of the motile parent thecae. The shape of the cyst resembles that of the theca with hypocystal horns to the posterior direction, but has shorter horns and a more circular central body in cross section. The cysts of extant marine Neoceratium candelabrum and N. furca (Gomez et al. 2010) both possess hypocystal horns to the posterior direction as parent thecae, so it is not yet known if other marine species may be capable of producing cysts with hypocystal horns to the anterior direction (recurved).

\subsection{Morphological variability of horns in Cretaceous ceratiacean cysts}

Major morphological features for the identification of fossil ceratiacean genera are: the length, number, prominence and orientation of horns; the number of walls; the distribution of cavation; the presence or absence of processes; and whether the operculum is free or adnate (attached). The two lateral horns of Phoberocysta and Muderongia are similar in size. This contrasts with Endoceratium, Odontochitina, Odontochitinopsis, Pseudoceratium and Xenascus in which the two lateral horns are markedly unequal, with the right lateral horn being larger and the left lateral horn being accessory. The number of horns plus the presence or absence of processes allows recognition of the following generic groups: the Phoberocysta/Muderongia complex, the former genus with two lateral and isolated processes, and the latter with the same number of horns but without processes; and the Xenascus/Odontochitina complex, the former genus with one lateral horn and processes, and the latter also with one lateral horn but devoid of processes. Two related genera that show a similar differentiation in ornamentation are Endoceratium and Pseudoceratium, the former lacking ornamentation on the periphragm and the latter bearing processes that are linked distally. In Aptea the horns are reduced and the autophragm is partially covered by an ectophragm. Genera without a subspherical central body possess horns which are reduced, but which may be equal or unequal in size, save for Balmula which has horns extended.

There are two published records of Cretaceous ceratiacean cysts with filamentous appendages. A specimen of Muderongia staurota with long appendages at the extremities of the apical, lateral and antapical horns was illustrated by Monteil (pl. 5, fig. 7, pl. 11, fig. 3 in 1991). This variant of Muderongia staurota came from a Total-CFP borehole located offshore southeastern Argentina. The second record from Núñez-Betelu \& Hills (1998) who described Odontochitina octopus with filamentous appendages extending from the distal tips of the horns. The species was found in Coniacian (85 Ma) sediments of the Kanguk Formation (Sverdrup Basin of Arctic Canada).

Monteil (1991, p. 490, in the caption to pl. 5, fig. 7) noted that one specimen of Muderongia staurota had 'perforated-ragged horn extremities with free sutures'. The specimen exhibits filamentous independent appendages which are, according Monteil, free by the absence of the sutures. On the apical horn, the four appendages are not all at the distal extremity; two are emerging from mid length. Núñez-Betelu \& Hills (1998) described Odontochitina octopus as having four distal filamentous terminations on the apical horns and two terminations on both the lateral and antapical horns. These authors linked the number of appendages with the number of plates forming the horns, and explained the terminations as representing detachment of the plates at the mid-length of each horn. They noted gradational forms between Odontochitina costata and O. octopus, and proposed the development of filamentous appendages as the result of the coalescence of the linear perforations found in O. costata.

\subsection{Environmental factors of ceratiacean cysts with filamentous appendages}

During the Early Cretaceous, Argentina was located near its present-day latitude. In contrast, India, which is now located in the Northern Hemisphere, was, during the Early Cretaceous, in the Southern Hemisphere close to Antarctica. Muderongia staurota with filamentous appendages (Monteil 1991) and Muderongia gangapurensis sp. nov. were therefore present under high latitudes $\left(\approx 60^{\circ} \mathrm{S}\right)$ of the Southern Hemisphere. A similar palaeogeographical argument can be used for Odontochitina octopus. Indeed, during the Late Cretaceous, Arctic Canada was located near its present-day latitude. Odontochitina octopus (Núñez-Betelu \& Hills 1998) was therefore present in high latitudes of the Northern Hemisphere $\left(\approx 70^{\circ} \mathrm{N}\right)$. According to published data, the restriction of such 
morphotypes to high latitudes suggests that temperature may have been one of the triggering mechanisms for the development of filamentous appendages, perhaps brought on by increasing stress. According to the temperature gradients, from pole to pole, temperatures in high latitudes are lower than those from low latitudes.

Monteil (1991) did not specify the nature of sediments. Odontochitina octopus is restricted to an organic-rich papery mudstone in association with prasinophytes and acritarchs at both Glacier Fiord and Mountain Bridgman localities (NúñezBetelu \& Hills 1998). Muderongia gangapurensis sp. nov. is associated with grey shale with carbonaceous matter coming from deltaic inputs. Thus, cysts with filaments at the end of their horns formed in water rich in organic matter. Perhaps such environments were a factor in the development of filamentous ceratiaceans.

\section{Conclusion}

Muderongia staurota and Muderongia gangapurensis sp. nov. have similar morphology and we suggest that Muderongia gangapurensis sp. nov. may be a phenotypic cyst of the mother cell producing Muderongia staurota, due to the influence of environmental factors such as light, salinity and temperature, and chemical factors such as $\mathrm{pH}$ and elemental concentrations. The new species were living in a deltaic environment of Early Cretaceous, rich in organic matter. As of now, we have not observed gradational forms in our samples that parallel Odontochitina costata and O. octopus. Unstable environments with rich organic matter, such as deltaic ones, might have triggered the development of free appendages on Cretaceous ceratiacean cysts. We try to explain the isolated appendages of Muderongia gangapurensis sp. nov. by a decreasing of the dinosporin during the encystment leading to the absence of welding of sutures and the reduction of the plates.

In the fossil record and in the living species, the plasticity of horns of the Ceratiaceae is one of the major features for differentiating genera and species. The development of filamentous appendages on horns was a rare feature of Ceratiaceae evolution. Comparing the appendages in Neoceratium ranipes with those in Odontochitina octopus and Muderongia gangapurensis sp. nov. is risky because they have different physiological origins. The former is on thecae, with a photosynthetic role; the latter form during encystment. However, the plasticity of horn morphology of cysts seems to have been a recurring characteristic during at least the Early Cretaceous ( $\sim 145 \mathrm{Ma})$ evolution of the Ceratiaceae.

\section{Systematics}

We are introducing the term 'unitabular' to describe the proximal posterior extension of lateral horn, and the term 'disunitabular' to define the distal posterior extension, the filamentous appendages. We accept the interpretation of Wall \& Evitt (1975) that there is one posterior intercalary plate (1p) and one antapical plate (1"') instead of two antapical plates $\left(1^{\prime \prime \prime \prime}=1 \mathrm{p}, 2^{\prime \prime \prime \prime}=1^{\prime \prime \prime \prime}\right)$. We are following the International Code of Nomenclature for algae, fungi and plants: (Melbourne
Code): http://www.iapt-taxon.org/nomen/main.php. The taxonomic nomenclature used here for fossil dinoflagellate cysts followed DINOFLAJ2 Fensome RA, MacRae RA \& Williams GL 2008. DINOFLAJ2 Version 1. American Association of Stratigraphic Palynologists, Data Series no. 1. A taxonomic list of genera and species cited in the text is available online (in the Supplemental data).

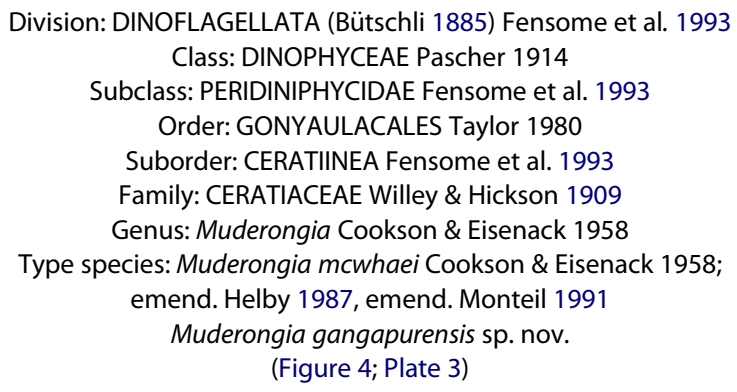

Holotype. Plate 3, figures 1, 4, borehole MJR-11, depth level 36.50 m, BSIP Museum slide no. 15255, England Finder (M45-2).

Paratype. Plate 3, figure 2, borehole MJR-11, depth level 46.40 m, BSIP Museum slide no. 15256, England Finder (W32-2).

Type locality and horizon. Jangareddygudem (Andhra Pradesh), Gangapur Formation, Upper Gondwana, Chintalapudi Sub-Basin, India; Hauterivian/Barremian.

Housed. Birbal Sahni Institute of Palaeosciences (BSIP) Museum collection, Lucknow, India.

Synonym. Muderongia staurota in Monteil 1991 (pl. 5, fig. 7, pl. 11, fig. 3).

Derivation of name. gangapurensis (Latin) for Gangapur Formation of the Upper Gondwana Group.

Diagnosis. Ceratioid proximochorate cyst, cornucavate, delphicavate to circumcavate, compressed dorso-ventrally and twolayered. Endophragm subspherical, periphragm with four horns: one apical, two laterals and one antapical. Horns proximally unitubular, distally perforated and extended into disunitabular plates, the filamentous appendages, four from the apical horn and two from each of the others. Archeopyle apical, type ( $t A)$, tabulation: ?pr, 4', 0a, 6", 6c, 6"', 1p, 1'"' indicated by archeopyle margins and accessory sutures, sulcal notch marked.

Description. Cyst with ceratioid outline, two-layered, with thin periphragm and endophragm, cornucavate, delphicavate (lateral pericoel connected with antapical pericoel) to circumcavate. Endophragm subspherical. Periphragm developed into four horns, one axial apical horn, two sub-equal lateral horns and one axial antapical horn. Each horn has a unitabular proximal part and disunitabular distal part developing filamentous appendages not divided along their length. The two sub-equal lateral horns have a broad proximal part in line with the cingulum and are comprised of precingular, cingular and postcingular plates. The left lateral horn includes precingulars 1", 2", one or two cingulars and postcingulars $1^{\prime \prime \prime}, 2^{\prime \prime \prime}$. The right lateral horn 

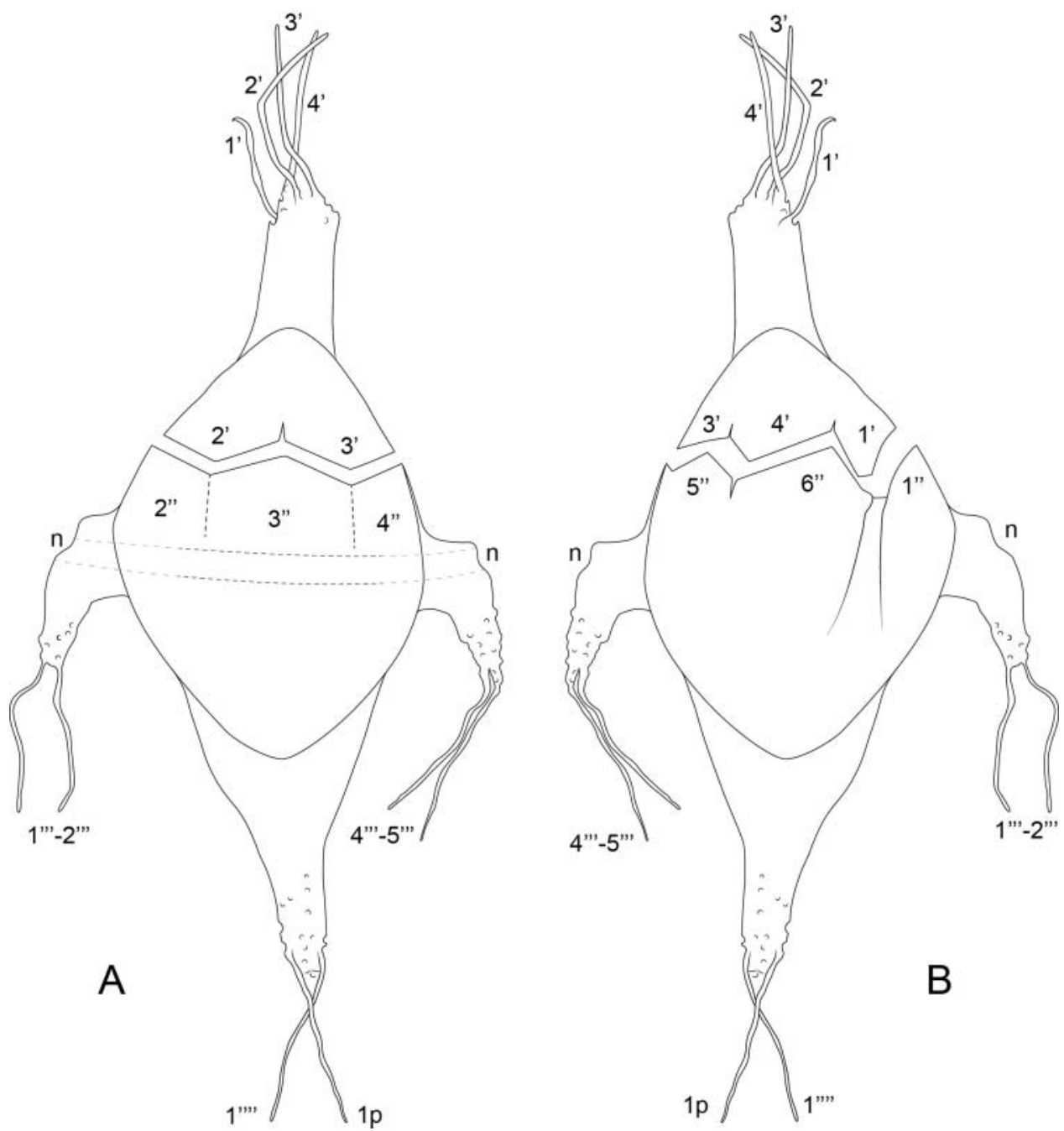

Figure 4. Tabulation of Muderongia gangapurensis sp. nov. holotype; $A$, dorsal face; $B$, ventral face, $n=$ lateral notch.

comprises precingulars $4^{\prime \prime}, 5^{\prime \prime}$, one or two precingulars and postcingulars $4^{\prime \prime \prime}, 5^{\prime \prime \prime}$. The distal parts in the posterior direction of each lateral horn involve postcingular plates only. The number of appendages is related to the tabulation of horns: the four apical appendages $\left(1^{\prime}, 2^{\prime}, 3^{\prime}, 4^{\prime}\right)$ extend from the distal end of the apical horn; the two left lateral appendages extend from the $1 " ', 2$ '" plates, the two right lateral ones from the $4 " ', 5$ "' plates; the two antapical appendages are in continuity with the 1 '"' and 1p. The endophragm is ovoid. Archeopyle apical, type $\mathrm{t} A$, with angular margin and marked sulcal notch, operculum free. Tabulation formula: ?pr, 4', 0a, 6", 6c, 6"', $1 p, 1^{\prime \prime \prime}$ : tabulation indicated by principal and accessory sutures of archeopyle. Cingulum indicated by dorsal folds and lateral notches in cross-section and sulcus underlined by folds.

Dimensions. Twenty-three specimens observed, five specimens measured because they were not folded.

Holotype. Total length $206 \mu \mathrm{m}$, total width $84 \mu \mathrm{m}$, apical horn with appendages $68 \mu \mathrm{m}$ appendages (unitubular horn $33 \mu \mathrm{m}$, filamentous appendages $35 \mu \mathrm{m}$ ); central body, length $84 \mu \mathrm{m}$, width $64 \mu \mathrm{m}$; lateral horn with appendages $45 \mu \mathrm{m}$ (unitubular horn $20 \mu \mathrm{m}$, filamentous appendages $25 \mu \mathrm{m}$ ); antapical horn with appendages $55 \mu \mathrm{m}$ (unitabular horn $33.5 \mu \mathrm{m}$, filamentous appendages $21.5 \mu \mathrm{m}$ ).

Paratype. Total length $209 \mu \mathrm{m}$, total width $71 \mu \mathrm{m}$; central body, length $83 \mu \mathrm{m}$, width $59 \mu \mathrm{m}$; apical horn $67 \mu \mathrm{m}$ (unitubular horn $26 \mu \mathrm{m}$, filamentous appendages $41 \mu \mathrm{m}$ ); lateral horn with appendages $59 \mu \mathrm{m}$ (unitubular horn $47 \mu \mathrm{m}$, filamentous appendages $12 \mu \mathrm{m}$ ); antapical horn $59 \mu \mathrm{m}$ (unitubular horn 34 $\mu \mathrm{m}$, filamentous appendages $25 \mu \mathrm{m})$.

Total length: 180 (203) $241 \mu \mathrm{m}$.

Comparison. Helby (1987, p. 298, Fig. 1) recognized two major morphological groups with a continuum of species in Muderongia. One group has broad-based lateral horns with variable development of the posterior extensions, relatively short to moderate apical and antapical horns with rounded distal extremities of all horns. The right antapical horn is nearly the same size and shape as the left antapical for $M$. testudinaria, markedly reduced for $M$. simplex, $M$. perforata, $M$. australis and M. mcwhaei, or absent for M. staurota and M. tomaszowensis. Muderongia simplex, M. perforata and $M$. tomaszowensis differ from the other species by their shorter lateral horns without posterior extensions. The other group has long pointed horns: one apical, two laterals without a broad-based proximal part, 

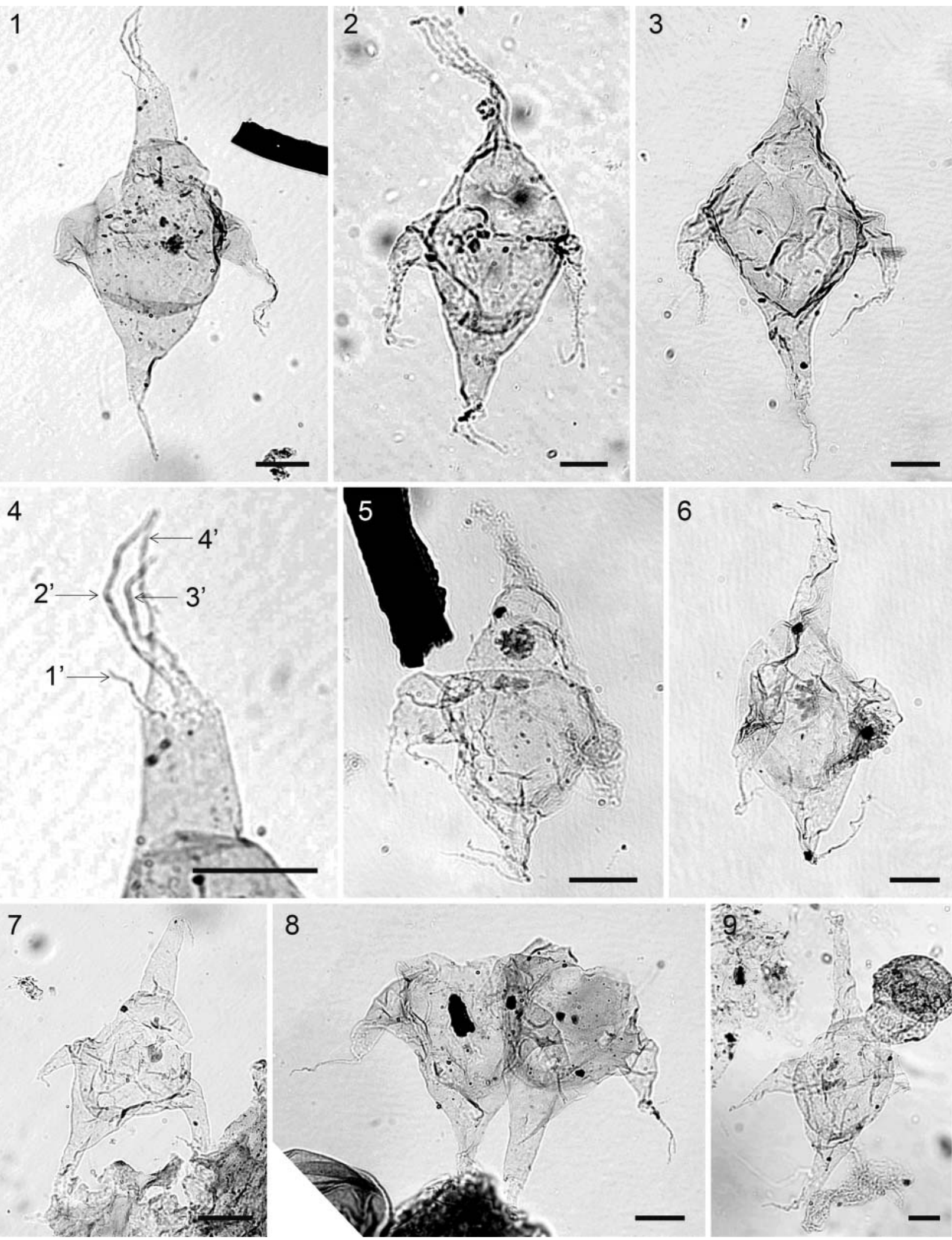

8

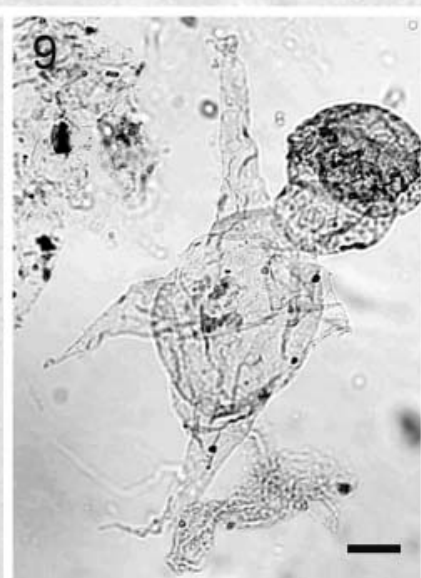

Plate 3. Muderongia gangapurensis sp. nov. from Chintalapudi Sub-Basin, Andhra Pradesh; co-ordinates: Graticule England Finder (GEF). Scale bars $=20 \mu \mathrm{m}$. 1: Holotype, cyst with operculum, focus on the dorsal face; the cingulum is delineated, perforated periphragm on distal part of horns. Four filamentous appendages extend at the distal end of the apical horn; MJR-11 36.50 m, BSIP Museum slide no. 15255 GEF: M45-2. 2: Paratype, cyst with operculum, focus on the ventral face; sulcal notch and principal and accessory sutures are well expressed, four filamentous appendages prolong the apical horn, lateral horns and antapical one bear two filamentous appendages, MJR-11 46.40 m, BSIP Museum slide no. 15256 GEF: W32-2. 3: Cyst with operculum, focus on ventral face; the four apical filamentous appendages are bent, but note their insertions; the other appendages are not well expressed, MJR-11 $46.40 \mathrm{~m}$, BSIP Museum slide no. 15257 GEF: T 47-2. 4: Detail of the distal part of the apical horn of the holotype. Four apical filamentous appendages raised from performed periphragm. The four apical appendages are in continuity with the four apical plates suggesting that each appendage is a single plate (1', 2', 3', 4'), MJR-11 46.40 m, BSIP Museum slide no. 15255 GEF: M45-2. 5: Cyst with operculum, overview. At the distal end of one lateral horn, two filamentous appendages prolong the two postcingular plates, filamentous appendages are well developed on the antapical horn (1"'m, 1p), MJR-11 $46.40 \mathrm{~m}$, BSIP Museum slide no. 15258 GEF: Q 62. 6: Cyst with operculum; the apical, lateral and antapical long filamentous appendages extend horns, MJR-11 $46.40 \mathrm{~m}$, BSIP Museum slide no. 15259 GEF: T67-1. 7: Cyst with operculum, focus on the dorsal face; appendages are damaged, MJR-11 46.40 m, BSIP Museum slide no. 15260 GEF: S63-2. 8: Couple of cysts without operculum, distal ends of horns are finely perforated and lateral horns show long appendages, MJR-11 $36.50 \mathrm{~m}$, BSIP Museum slide no. 15255 GEF: V55. 9: Cyst with operculum; note the antapical insertion of the two filamentous appendages, MJR-11 46.40 m, BSIP Museum slide no. 15258 GEF: X36-2. 
and a single antapical. This group includes $M$. extensiva and $M$. tetracantha. Muderongia gangapurensis sp. nov. can be integrated into the first group. Muderongia gangapurensis sp. nov. and Muderongia staurota have the same shape, broad-based lateral horns with long unitabular posterior extensions and the right antapical horn absent. They differ by their horns' extremities; $M$. gangapurensis sp. nov. has filamentous appendages while $M$. staurota does not. Muderongia australis has a broadbased lateral horn but differs from $M$. staurota and $M$. gangapurensis sp. nov. by shorter lateral posterior extensions and a tiny right antapical horn. Muderongia mcwhaei has long posterior extensions and a tiny right antapical horn. Helby (1987, p. 298) noted that 'species differentiation in this group is often difficult'.

\section{Acknowledgements}

We are thankful to the Director of BSIP for providing the facilities for the research work. Thanks are due to Sri M. Basawa Chari, CGM (Exploration), Singareni Collieries Company Limited, India, for support during collection of samples and providing necessary details. G. Williams, J. Riding and an anonymous reviewer are thanked for their meticulous review of the manuscript and their constructive remarks. We are also indebted to 'Centre de Recherche sur la paléobiodiversité et les paléoenvironnements, UMR 7207', and Alexandre Lethiers for his help with figures and plates.

\section{Disclosure statement}

No potential conflict of interest was reported by the authors.

\section{References}

Balech E. 1988. Los dinoflagelados del Atlántico Sudoccidental. Publ. Espec., Instuto Español de Oceanografía, Ministerio de Agricultura Pesca y alimentación no. 1, Madrid; p. 310.

Below R. 1982. Scolochorate Zysten der Gonyaulacaceae (Dinophyceae) aus der Unterkreide Marokkos. Palaeontographica B 182:1-51.

Bharadwaj DC, Saluja SK. 1964. Sporological study of Seam VIII in Raniganj Coalfield, Bihar (India) part -1. Description of sporae dispersae. Palaeobotanist 12:181-125.

Bint AN. 1986. Fossil ceratiaceae: A restudy and new taxa from the Mid-Cretaceous of the Western Interior, U.S.A. Palynology 10:135-180.

Bose MN, Kutty TS, Mahesweari HK. 1982. Plant fossils from the Gangapur Formation. Palaeobotanist 30:121-125.

Bütschli O. 1885. Erster Band. Protozoa. In: Dr. H.G. Bronn's Klassen und Ordnungen des Thier-Reichs, wissenschaftlich dargestellt in Wort und Bild. Leipzig and Heidelberg, Germany: CF Winter'sche Verlagshandlung;p. 865-1088.

Cleve PT. 1900. Notes on some Atlantic plankton organisms. Kongl. Svenska Vetenskaps Academiens Handlingar 34:1-22.

Costa LI, Davey RJ. 1992. Dinoflagellate cysts of the Cretaceous System. In: Powell AJ, editor. A stratigraphic index of dinoflagellate cysts. London: Chapman \& Hall; p. 99-153.

Dowidar NM. 1972. Morphological variations in Ceratium egyptiacum in different natural habitats. Marine Biology 16: 138-149.

Duane AM. 1997. Taxonomic investigations of palynomorphs from the Byers Group (Upper Jurassic - Lower Cretaceous), Livingston and Snow Islands, Antarctic Peninsula. Palynology 21:123-144.

El-Mehdawi AD. 1998. Odontochitina tabulata sp. nov. A late Santonian-early Campanian dinoflagellate cyst from SE Sirte Basin, Libya. Journal of Micropalaeontology 17:173-178.

Entz G. 1925. Über Cysten und Encystierung der Sûsswasser-Ceratien. Arch. Protistenk 58:131-183.

Evitt WR. 1985. Sporopollenin dinoflagellate cysts: their morphology and interpretation. American Association of Stratigraphic Palynologists Foundation, Dallas, USA; p. 333.

Fensome RA, Taylor FJR, Norris G, Sarjeant WAS, Wharton DI, Williams GL. 1993. A classification of living and fossil dinoflagellates. American
Museum of Natural History, Micropaleontology special publication, 7. Sheridan Press, Hanover, USA; p. 351.

Garg R, Khowaja-Ateequzzaman , Jain KP. 1987. Jurassic and lower cretaceous dinoflagellate cysts from India with some remarks on the concept of Upper Gondwana. Palaeobotanist 36:257-267.

Gómez F, Moreira D, Lopez-Garcia P. 2010. Neoceratium gen. nov., a new genus for all marine species currently assigned to Ceratium (Dinophyceae). Protists 161:35-54.

Gran HH. 1902. Das Plankton des Norwegischen Nordmeeres. Rep. Norw. Fish Mar Invest 2:1-222.

Harding IC, Hughes NF. 1990. Fossil ceratioid: A revision of Endoceratium dettmannae from the early Cenomanian Cambridge Greensand. Review of Palaeosciences and Palynology 65:311-318.

Helby R. 1987. Muderongia and related dinoflagellates of the latest Jurassic to Early Cretaceous of Australia. In: Jell PA, editor. Studies in Australian Mesozoic Palynology. Sydney: Memoir 4 of Association of Australasian Palaeontologists; p. 297-336.

Helby R, Morgan R, Partridge AD. 1987. A palynological zonation of the Australian Mesozoic. In: Jell PA, editor. Studies in Australian Mesozoic Palynology. Sydney: Memoir 4 of Association of Australasian Palaeontologists; p. 1-94.

Jain KP. 1977. Additional dinoflagellates and acritarchs from Grey Shale Member of Dalmiapuram Formation, South India. The Palaeobotanist 24:170-194.

Jha N, Prakash N, Joshi H. 2016. Integrated palaeobotany and palynological analysis of subsurface Gondwana sedimentary succession (Jurassic-Cretaceous) in Jangareddygudem area, Chintalapudi Sub-Basin, South India: Stratigraphical and phytogeographical implications. Palaeoworld Available from: https://doi.org/10.1016/j.palwor.2016.03.002

Khowaja-Ateequzzaman, Jain KP. 1992. Hauterivian-Barremian dinoflagellate cyst assemblage from subsurface of Palar Basin, southern India. In: Venkatachala BS, Jain KP, Awasthi N, editors. Proceeding of Birbal Sahni Birth Centenary Paleobotanical Conference, Lucknow. Geophytology; 22:133-180.

Kofoid CA. 1907. The plates of Ceratium with a note in the unity of the genus. Zoologischer Anzeiger 32:177-193.

Kofoid CA. 1908. Exuviation, autotomy and regeneration in Ceratium. University of California Publications in Zoology; 4/6: 345-386.

Kofoid CA. 1909. Mutations in Ceratium. Bulletin of the Museum of Comparative Zoology at Harvard college 52:213-257.

Laksminarayana G, Murti KS. 1990. Stratigraphy of the Gondwana Formations in the Chintalapudi sub-basin, Godavari Valley, Andhra Pradesh. Journal of the Geological Society of India 36:13-35.

Mao S, Chunbiao W, Xiayun Q. 1999. Cretaceous nonmarine dinoflagellates from northeast China. Grana 38:144-161.

Monteil E. 1991. Morphology and systematics of the ceratioid group; a new morphographic approach; revision and emendation of the genus Muderongia Cookson \& Eisenack 1958. Bulletin des Centres de Recherche exploration-production Elf-Aquitaine 15:465-505.

Morgan R. 1980. Palynostratigraphy of the Australian Early and middle Cretaceous. Memoirs of the Geological Survey of New South Wales, Palaeontology 18: p. 153.

Müller OF. 1786. Animacula infusoria fluviatilia et marina, quae detexit, systematice descripsit et ad vivum delineari curavit. Copenhagen and Leipzig: Typis N. Mölleri; p. 544.

Nielsen J. 1956. Temporary variations in certain marine Ceratia. Oikos 7:256272.

Núñez-Betelu K, Hills LV. 1998. A late Coniacian dinoflagellate cyst, Odontochitina octopus sp. nov., from the Kanguk Formation, Canada Arctic Canadian Journal of Earth Sciences 35:923-931.

Ostenfeld CH. 1903. Phytoplankton from the sea around the Faeröes. In: Part II, Warming E, editors. Botany of the Faeröes based upon Danish investigations. Copenhagen: Det Nordiske Forlag Ernst Bojesen; p. 558-612.

Paulsen O. 1908. XVIII Peridiniales. In: Brandt K, Apstein C, editors. Nordisches Plankton. Kiel and Leipzig: Linsius \& Tischer; p. 1-124.

Pizay MD, Lemée R, Simon N, Cras AL, Laugier JP, Dolan JR. 2009. Night and day morphologies in a planktonic dinoflagellate. Protist 160:565-575.

Schrank F von Paula. 1793. Mikroskopische Wahrnehmungen. Der Naturforscher (Halle) 27:26-37. 
Sournia A. 1967. Le genre Ceratium (Péridinien planctonique) dans le canal de Mozambique. Contribution à une révision mondiale. Vie et Milieu série A 18:375-499.

Sournia A. 1984. Classification et nomenclature de divers dinoflagellés marins (classe des Dinophyceae). Phycologia 23:345-355.

Sournia A. 1986. Atlas du phytoplancton marin. Introduction, Cyanophycées, Dictyochophycées, Dinophycées et Raphidophycées. Paris: Edition du CNRS; p. 219.

Steidinger KA, Jangen K. 1997. Dinoflagellates. In: Tomas CR, editor. Identifying Marine Phytoplanction. San Diego: Academic Press; p. 387-584.

Sukh-Dev, Rajanikanth A. 1988. The Gangapur formation: fossil flora and stratigraphy. Geophytology 18:1-27.

Taylor FJR. 1987. Dinoflagellate morphology. In: Taylor FJR, editor. The biology of Dinoflagellates. Oxford: Blackwell; p. 24-91.

Temponeras M, Kristiansen J, Moustaka-Gouni M. 2000. A new Ceratium species (Dinophyceae) from Lake Dorani, Macedonia Hreece. Hydrobiologia 424:101-108.
Tunin-Ley A, Lemée R. 2013. The Genus Neoceratium (Planktonic Dinoflagellates) as a Potential Indicator of Ocean Warming. Microorganisms 1:5870. doi:10.3390/microorganisms 1010058

Vanhöffen R. 1896. Das Genus Ceratium. Zoologischer Anzeiger 19:133-134. Vijaya . 1999. Palynological dating of the Neocomian-Aptian succession in the Indian peninsula. Cretaceous Research 20:597-608.

Wall D, Evitt WR. 1975. A comparison of the modern genus Ceratium Schrank, 1793, with certain Cretaceous marine dinoflagellates. Micropaleontology 24:14-44.

Willey A, Hickson SJ. 1909. The Protozoa (continued). Section F.-The Mastigophora. In: First Fascicle, Lankester RA, Black C, editors. A treatise on Zoology. Part 1. Introduction and Protozoa. London: Reprinted by Asher, A. Amsterdam; 1964 p. 154-192.

Williams GL. 1978. Palynological biostratigraphy, Deep Sea Drilling Project, Sites 367 and 370, Leg 41. In: Lancelot Y, Seibold E, et al. editors. Init. Report DSDP. Washington (US Govt. Printing Office) suppl. to 38-41; p. 783-815. 